\title{
Corynebacterium pilbarense sp. nov., a non- lipophilic corynebacterium isolated from a human ankle aspirate
}

\author{
M. Aravena-Roman, ${ }^{1}$ C. Spröer, ${ }^{2}$ B. Sträubler, ${ }^{2}$ T. Inglis ${ }^{1}$ and A. F. Yassin ${ }^{3}$ \\ ${ }^{1}$ Division of Microbiology and Infectious Diseases PathWest Laboratory Medicine, OEII MC Locked \\ Bag 2009 Nedlands WA 6909, Australia \\ ${ }^{2} \mathrm{DSMZ}$ - Deutsche Sammlung von Mikroorganismen und Zellkulturen GmbH, Inhoffenstraße 7b, D- \\ 38124 Braunschweig, Germany \\ ${ }^{3}$ Institut für Medizinische Mikrobiologie und Immunologie der Universität Bonn, Sigmund-Freud- \\ Straße 25, 53127 Bonn, Germany
}

Correspondence

A. F. Yassin

yassin@mibi03.meb.uni-bonn.de
The genus Corynebacterium is one of the largest genera within the class Actinobacteria and currently embraces over 82 species, a high proportion of which have been defined over the past decade. Some corynebacteria are wellestablished pathogens of man and animals, whereas many others occur as part of the normal flora of skin and mucous membranes (Soriano and Fernandez-Roblas, 1988; Coyle \& Lipsky, 1990; Colt et al., 1991; Sewell et al., 1995). As some of these diphtheroids show a lipid requirement for growth, which can be supplied by serum or Tween 80 , these strains have often been referred to as lipophilic diphtheroids. Attempts to classify these organisms on the basis of biochemical characteristics have been undertaken. The Centers for Disease Control and Prevention (CDC; Atlanta, Georgia, USA) separated lipophilic diphtheroids into groups ANF-1, G-1 and G-2 in addition to groups JK (Corynebacterium jeikeium) and D-2 (Corynebacterium urealyticum) using biochemical tests (Riley et al., 1979; Hollis \& Weaver, 1981; Riegel et al., 1992, 1993). After several different taxonomic studies, it was concluded that

The GenBank/EMBL/DDBJ accession number for the 16S rRNA gene sequence of strain IMMIB WACC $658^{\top}$ is FN295567. the strains formerly named as CDC group G-1 represent at least two species, Corynebacterium macginleyi (Riegel et al., 1995) and Corynebacterium accolens (Neubauer et al., 1991). Other glucose-fermenting lipid-requiring strains that do not hydrolyse urea are now known as Corynebacterium tuberculostearicum (Brown et al., 1984; Feurer et al., 2004). During the course of characterization of bacterial isolates encountered from clinical sources, we found a Gram-positive, pleomorphic to rod-shaped, glucose-fermenting bacterium that did not hydrolyse urea. The API Coryne profile assigned the organism to CDC group G. Further chemotaxonomic and phylogenetic investigations confirmed its assignment to the genus Corynebacterium and indicated that it was different from previously described species of the genus. Based on both phenotypic and phylogenetic evidence, we propose that this strain represents a novel species of the genus Corynebacterium.

Strain IMMIB WACC $658^{\mathrm{T}}$ was isolated from anaerobic Bactec bottles inoculated with ankle aspirate from a 54year-old man, probably with gout (urate crystals present in the joint fluid) in Pilbara, West Australia. The strain was 
submitted to the Reference Laboratory of the Institute of Medical Microbiology, University of Bonn, Germany, for identification. The isolate was cultured on Columbia blood agar supplemented with $5 \%$ sheep blood to determine its morphological properties. Lipophilic requirement was determined according to standard procedures (Riegel et al., 1994). Fermentation and enzymic tests were performed using the API Coryne, API 20 Strep and the API ZYM systems according to the manufacturer's instructions (bioMérieux), except for the time of incubation. Enzyme reactions and acid production from carbohydrates, using the API Coryne and API Strep systems, were read after $48 \mathrm{~h}$ incubation at $37^{\circ} \mathrm{C}$. The isomeric form of diaminopimelic acid was determined by the methods of Becker et al. (1964) and whole-cell sugars were determined according to the method of Lechevalier (1968). Lipids were extracted using acid methanolysis and mycolic acids were detected with TLC as described by Minnikin et al. (1980). A standard procedure was used to determine the fatty acid profile (Minnikin et al., 1980; Yassin et al., 2007).

For phylogenetic analysis, 16S rRNA genes were amplified by PCR using procedures described previously (Rainey et al., 1996) and directly sequenced using a Taq dye-deoxy terminator cycle sequencing kit (Applied Biosystems) and an automatic DNA sequencer (model 310; Applied Biosystems). The closest relatives of the isolate were determined by performing database searches. Phylogenetic analysis was carried out as previously described (Yassin, 2009) using the ARB-package (Ludwig et al., 2004). DNADNA relatedness studies were performed between strain IMMIB WACC $658^{\mathrm{T}}$ and C. ureicelerivorans DSM $45051^{\mathrm{T}}$. DNA was isolated using a French pressure cell (Thermo Spectronic) and was purified by chromatography on hydroxyapatite as described by Cashion et al. (1977). DNA-DNA hybridization was carried out as described by De Ley et al. (1970) with consideration of the modifications described by Huß et al. (1983) using a model Cary 100 Bio UV/VIS-spectrophotometer equipped with a Peltierthermostatted $6 \times 6$ multicell changer and a temperature controller with an in situ temperature probe (Varian).

Strain IMMIB WACC $658^{\mathrm{T}}$ was Gram-positive, nonmotile, non-spore-forming and had pleomorphic to short rod-shaped cells. On Columbia blood agar, circular, large colonies (approx. 0.5-2.0 mm diameter) were formed after $24 \mathrm{~h}$ incubation at $37^{\circ} \mathrm{C}$. The colonies were nonhaemolytic. The organism was facultatively anaerobic and was catalase-positive, but oxidase- and urease-negative. The API Coryne numerical profile was 6100305, which corresponded to the numerical profile for Corynebacterium group G (ID 96.7\%). However, the main difference between strain IMMIB WACC $658^{\mathrm{T}}$ and Corynebacterium group $\mathrm{G}$ was that the latter includes lipid-requiring strains, whereas strain IMMIB WACC $658^{\mathrm{T}}$ was non-lipophilic. An examination of cell-wall murein acid hydrolysates of the novel strain revealed the presence of meso-diaminopimelic acid as the dibasic amino acid. TLC analysis of cell-wall sugars revealed the presence of galactose and arabinose, i.e. the organism had cell-wall chemotype IV sensu Lechevalier \& Lechevalier (1970). Lipid analysis revealed the presence of corynemycolic acids. Examination of the nonhydroxylated long-chain cellular fatty acids of the novel strain showed the presence of straight-chain saturated $\mathrm{C}_{16: 0}(31.6 \%), \mathrm{C}_{17: 0}(0.5 \%), \mathrm{C}_{18: 0}(10.9 \%)$, monounsaturated $\mathrm{C}_{16: 1} \omega 7 c(0.4 \%), \mathrm{C}_{17: 1} \omega 9 c(0.1 \%), \mathrm{C}_{18: 1} \omega 9 c$ (56.0\%) and cis-9,12-octadecadienoic acid $\mathrm{C}_{18: 2}(0.4 \%)$. Tuberculostearic acid was not detected. These chemotaxonomic characteristics, together with the morphological and biochemical properties of isolate IMMIB WACC $658^{\mathrm{T}}$, were strongly indicative that the organism belonged to the genus Corynebacterium.

To establish the phylogenetic position of strain IMMIB WACC $658^{\mathrm{T}}$, its $16 \mathrm{~S}$ rRNA gene sequence $(1486 \mathrm{nt})$ was determined in this study. Sequence database searches revealed that strain IMMIB WACC $658^{\mathrm{T}}$ was most closely related to species of the genus Corynebacterium (data not shown). Phylogenetic analysis confirmed the placement of strain IMMIB WACC $658^{\mathrm{T}}$ within the genus Corynebacterium. A tree constructed using the neighbour-joining method showing the phylogenetic position of strain IMMIB WACC $658^{\mathrm{T}}$ in relation to members of the genus Corynebacterium is presented in Fig. 1. Comparative $16 \mathrm{~S}$ rRNA gene sequence analysis unequivocally demonstrated that the isolate represented a hitherto unknown species of the genus Corynebacterium that formed a distinct subline within a subcluster of species including the two subspecies of Corynebacterium afermentans, Corynebacterium coyleae, Corynebacterium mucifaciens and C. ureicelerivorans. Highest sequence similarity values were shown with $C$. ureicelerivorans ( $99.0 \%$ similarity), the two subspecies of $C$. afermentans $(98.9 \%)$, C. coyleae $(98.7 \%)$, and C. mucifaciens $(98.2 \%)$. Although the new strain showed close affinity with the aforementioned species, bootstrap resampling analysis showed that this association was not particularly significant. Significantly lower levels of sequence similarity were shown to other members of the genus Corynebacterium (data not shown).

Despite the high sequence similarity between isolate IMMIB WACC $658^{\mathrm{T}}$ and C. ureicelerivorans, the novel strain represented a distinct genomic species. It is now recognized that a $16 \mathrm{~S}$ rRNA gene sequence similarity range above $98.7-99 \%$ should be mandatory for establishing the genomic uniqueness of a novel isolate (Stackebrandt \& Ebers, 2006). In addition, the DNA-DNA relatedness study between strain IMMIB WACC $658^{\mathrm{T}}$ and C. ureicelerivorans DSM $45051^{\mathrm{T}}$ clearly demonstrated that the novel strain belonged to a separate genomic species. The mean DNADNA relatedness value was $39.5 \%$, a value well below the $70 \%$ cut-off point recommended for the assignment of strains to the same genomic species (Wayne et al., 1987). Strain IMMIB WACC $658^{\mathrm{T}}$ could also be distinguished from $C$. ureicelerivorans using a combination of phenotypic properties (Table 1). In addition, strain IMMIB WACC $658^{\mathrm{T}}$ could be differentiated from the frequently encountered species Corynebacterium amycolatum and 


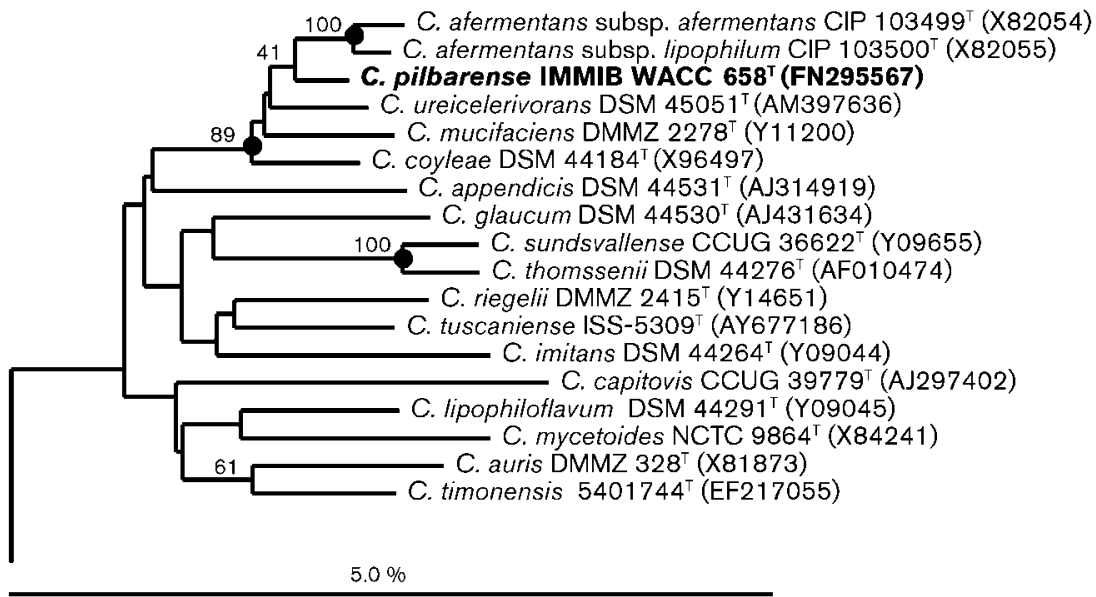

Fig. 1. Neighbour-joining phylogenetic tree showing the position of strain IMMIB WACC $658^{\top}$ within the radiation of species of the genus Corynebacterium. Numbers at nodes indicate the level of bootstrap support (\%) based on neighbour-joining analyses of 500 resampled datasets; solid circles indicate that the corresponding nodes (groupings) were also recovered in the maximum-likelihood and maximum-parsimony trees. Bar, $5.0 \%$ sequence divergence.
Corynebacterium minutissimum on the basis of the presence of mycolic acids and absence of tuberculostearic acid, respectively. The novel strain could also be differentiated from Corynebacterium striatum and the less frequently seen Corynebacterium simulans on the basis of nitrate reduction.

Thus the $1.0 \% \quad 16 \mathrm{~S}$ rRNA gene sequence divergence between strain IMMIB WACC $658^{\mathrm{T}}$ and its closest phylogenetic neighbour C. ureicelerivorans, together with the distinctive phenotype of strain IMMIB WACC $658^{\mathrm{T}}$ (Table 1), clearly demonstrated that this new isolate represents a novel species. Hence, on the basis of both phenotypic and phylogenetic evidence, the new strain merits classification as a novel species of the genus

Table 1. Characteristics that differentiate strain IMMIB WACC $658^{\top}$ from its closest phylogenetic relatives

Strains/species: 1, IMMIB WACC $658^{\mathrm{T}}$ (data from this study); $2, C$. ureicelerivorans IMMIB RIV-2301 ${ }^{\mathrm{T}}$ (data from this study); 3, C. mucifaciens (8 strains, Funke et al., 1997a); 4, C. afermentans subsp. afermentans CIP $103499^{\mathrm{T}}$ (Riegel et al., 1993); 5, C. afermentans subsp. lipophilum CIP $103500^{\mathrm{T}}$ (Riegel et al., 1993); 6, C. coyleae CCUG $35014^{\mathrm{T}}$ (Funke et al., 1997b); 7, C. macginleyi (Riegel et al., 1995); 8, C. accolens CIP $104783^{\mathrm{T}}$ (Neubauer et al., 1991); 9, C. tuberculostearicum (11 strains, Feurer et al., 2004). +, Positive; -, negative; $\mathrm{v}$, variable; ND, no data available.

\begin{tabular}{|lccccccccc|}
\hline Characteristic & $\mathbf{1}$ & $\mathbf{2}$ & $\mathbf{3}$ & $\mathbf{4}$ & $\mathbf{5}$ & $\mathbf{6}$ & $\mathbf{7}$ & $\mathbf{8}$ & $\mathbf{9}$ \\
\hline Lipid requirement & - & + & - & - & + & - & + & + & + \\
Nitrate reduction & - & - & - & - & - & - & + & + & $\mathrm{V}$ \\
Urease & - & + & - & - & - & - & - & - & - \\
Pyrazinamidase & + & + & + & + & + & + & - & + & + \\
Alkaline phosphatase & + & + & + & + & + & + & + & - & + \\
Acid production from & & & & & & & & & \\
$\quad$ Glucose & + & + & + & - & - & + & + & + & + \\
$\quad$ Maltose & - & - & - & - & - & - & - & + & $\mathrm{V}$ \\
$\quad$ Sucrose & + & - & $\mathrm{V}$ & - & - & - & + & $\mathrm{V}$ & $\mathrm{V}$ \\
Tuberculostearic acid & - & + & + & - & - & - & $\mathrm{ND}$ & $\mathrm{ND}$ & + \\
& & & & & & & & & \\
\hline
\end{tabular}

Corynebacterium, for which the name Corynebacterium pilbarense sp. nov. is proposed.

\section{Description of Corynebacterium pilbarense sp. nov.}

Corynebacterium pilbarense (pil.ba.ren'se. N.L. neut. adj. pilbarense pertaining to Pilbara, West Australia, the region from which the strain was isolated).

Cells are Gram-positive, non-spore-forming, non-motile, pleomorphic to short rods. Colonies are creamy, circular and approximately $0.5-2.0 \mathrm{~mm}$ in diameter on Columbia blood agar after $24 \mathrm{~h}$ incubation at $37^{\circ} \mathrm{C}$. Colonies are non-haemolytic. Facultatively anaerobic, catalase-positive and oxidase-negative. Non-lipophilic. Aesculin, gelatin and hippurate are not hydrolysed. Urease and nitrate reduction are negative. Acid is produced from D-glucose, D-ribose and sucrose. Acid is not produced from L-arabinose, glycogen, inulin, lactose, maltose, mannitol, raffinose, sorbitol, trehalose or D-xylose. Activity for alkaline and acid phosphatases, leucine arylamidase, pyrazinamidase, pyrrolidonyl arylamidase and naphthol-AS-BI-phosphohydrolase is detected. No activity is detected for arginine dihydrolase, esterase $\mathrm{C} 4$, ester lipase $\mathrm{C} 8, \alpha$-glucosidase, $\beta$ glucosidase, $\alpha$-galactosidase, $\beta$-galactosidase, $\beta$-glucuronidase, $\quad N$-acetyl- $\beta$-glucosaminidase, $\alpha$-mannosidase, $\alpha$ fucosidase, chymotrypsin, trypsin, valine arylamidase or cystine arylamidase. Acetoin production is negative. Mycolic acids are present. Long-chain fatty acids are of the straightchain saturated and monounsaturated types, with $\mathrm{C}_{16: 0}$ and $\mathrm{C}_{18: 1} \omega 9 c$ predominating; tuberculostearic acid is absent.

The type strain, IMMIB WACC $658^{\mathrm{T}}\left(=\mathrm{DSM} 45350^{\mathrm{T}}\right.$ $=$ CCUG $57942^{\mathrm{T}}$ ), was isolated from an anaerobic Bactec vial inoculated with an ankle aspirate from a man who was thought to be suffering from gout.

\section{Acknowledgements}

We thank Professor Dr Hans-Georg Trüper for his nomenclatural advice. 


\section{References}

Becker, B., Lechevalier, M. P., Gordon, R. E. \& Lechevalier, H. A. (1964). Rapid differentiation between Nocardia and Streptomyces by paper chromatography of whole cell hydrolysates. Appl Microbiol 12, 421-423.

Brown, S., Lanéelle, M. A., Asselineau, J. \& Barksdale, L. (1984). Description of Corynebacterium tuberculostearicum sp. nov., a leprosyderived Corynebacterium. Ann Microbiol (Paris) 135B, 251-267.

Cashion, P., Holder-Franklin, M. A., McCully, J. \& Franklin, M. (1977). A rapid method for base ratio determination of bacterial DNA. Anal Biochem 81, 461-466.

Colt, H. G., Morris, J. F., Marston, B. J. \& Sewell, D. L. (1991). Necrotizing tracheitis caused by Corynebacterium pseudodiphtheriticum: unique case and review. Rev Infect Dis 13, 73-76.

Coyle, M. B. \& Lipsky, B. J. (1990). Coryneform bacteria in infectious diseases: clinical and laboratory aspects. Clin Microbiol Rev 3, 227 246.

De Ley, J., Cattoir, H. \& Reynaerts, A. (1970). The quantitative measurement of DNA hybridization from renaturation rates. Eur $J$ Biochem 12, 133-142.

Feurer, C., Clermont, D., Bimet, F., Candréa, A., Jackson, M., Glaser, P., Bizet, C. \& Dauga, C. (2004). Taxonomic characterization of nine strains isolated from clinical and environmental specimens, and proposal of Corynebacterium tuberculostearicum sp. nov. Int J Syst Evol Microbiol 54, 1055-1061.

Funke, G., Lawson, P. A. \& Collins, M. D. (1997a). Corynebacterium mucifaciens sp. nov., an unusual species from human clinical material. Int J Syst Bacteriol 47, 952-957.

Funke, G., Ramos, C. P. \& Collins, M. D. (1997b). Corynebacterium coyleae sp. nov., isolated from human clinical specimens. Int J Syst Bacteriol 47, 92-96.

Hollis, D. G. \& Weaver, R. E. (1981). Gram-Positive Organisms: a Guide to Identification. Atlanta: Special Bacteriology Section, Centers for Disease Control.

Huß, V. A. R., Festl, H. \& Schleifer, K. H. (1983). Studies on the spectrophotometric determination of DNA hybridization from renaturation rates. Syst Appl Microbiol 4, 184-192.

Lechevalier, M. P. (1968). Identification of aerobic actinomycetes of clinical importance. J Lab Clin Med 71, 934-944.

Lechevalier, M. P. \& Lechevalier, H. A. (1970). Chemical composition as a criterion in the classification of aerobic actinomycetes. Int J Syst Bacteriol 20, 435-443.

Ludwig, W., Strunk, O., Westram, R., Richter, L., Meier, H., Yadhukumar, Buchner, A., Lai, T., Steppi, S. \& other authors (2004). ARB: a software environment for sequence data. Nucleic Acids Res 32, 1363-1371.

Minnikin, D. E., Hutchinson, I. G., Caldicott, A. B. \& Goodfellow, M. (1980). Thin-layer chromatography of methanolysates of mycolic acid-containing bacteria. J Chromatogr A 188, 221-233.
Neubauer, M., Sourek, J., Ryc, M., Bohacek, J., Mara, M. \& Mnukova, J. (1991). Corynebacterium accolens sp. nov., a gram-positive rod exhibiting satellitism, from clinical material. Syst Appl Microbiol 14, 46-51.

Rainey, F. A., Ward-Rainey, N., Kroppenstedt, R. M. \& Stackebrandt, E. (1996). The genus Nocardiopsis represents a phylogenetically coherent taxon and a distinct actinomycete lineage: proposal of Nocardiopsiaceae fam. nov. Int J Syst Bacteriol 46, 1088-1092.

Riegel, P., Grimont, P. A. D., De Briel, D., Ageron, E., Jehl, F., Pelegrin, M., Monteil, H. \& Monck, R. (1992). Corynebacterium group D2 ('Corynebacterium urealyticum') constitutes a new genomic species. Res Microbiol 143, 307-313.

Riegel, P., de Briel, D., Prévost, G., Jehl, F., Monteil, H. \& Minck, R. (1993). Taxonomic study of Corynebacterium Group ANF-1 strains: proposal of Corynebacterium afermentans sp. nov. containing the subspecies $C$. afermentans subsp. afermentans subsp. nov. and $C$. afermentans subsp. lipophilum subsp. nov. Int J Syst Bacteriol 43, 287292.

Riegel, P., de Briel, D., Prévost, G., Jehl, F. \& Monteil, H. (1994). Genomic diversity among Corynebacterium jeikeium strains and comparison with biochemical characteristics. J Clin Microbiol 32, 1860-1865.

Riegel, P., Ruimy, R., de Briel, D., Prévost, G., Jehl, F., Christen, R. \& Monteil, H. (1995). Genomic diversity and phylogenetic relationships among lipid-requiring diphtheroids from humans and characterization of Corynebacterium macginleyi sp. nov. Int J Syst Bacteriol 45, 128-133.

Riley, P. S., Hollis, D. G., Utter, G. B., Weaver, R. E. \& Baker, C. N. (1979). Characterization and identification of 95 diphtheroid (group JK) cultures isolated from clinical specimens. J Clin Microbiol 9, 418424.

Sewell, D. L., Coyle, M. B. \& Funke, G. (1995). Prosthetic valve endocarditis caused by Corynebacterium afermentans subsp. lipophilum (CDC coryneform group ANF-1). J Clin Microbiol 33, 759-761.

Soriano, F. \& Fernandez-Roblas, R. (1988). Infections caused by antibiotic-resistant Corynebacterium group D-2. Eur J Clin Microbiol Infect Dis 7, 337-341.

Stackebrandt, E. \& Ebers, J. (2006). Taxonomic parameters revisited: tarnished gold standards. Microbiol Today 33, 152-155.

Wayne, L. G., Brenner, D. J., Colwell, R. R., Grimont, P. A. D., Kandler, O., Krichevsky, M. I., Moore, L. H., Moore, W. E. C., Murray, R. G. E. \& other authors (1987). International Committee on Systematic Bacteriology. Report of the ad hoc committee on reconciliation of approaches to bacterial systematics. Int J Syst Bacteriol 37, 463-464.

Yassin, A. F. (2007). Corynebacterium ureicelerivorans sp. nov., a lipophilic bacterium isolated from blood culture. Int J Syst Evol Microbiol 57, 1200-1203.

Yassin, A. F., Chen, W. M., Hupfer, H., Siering, C., Kroppenstedt, R. M., Arun, A. B., Lai, W. A., Shen, F. T., Rekha, P. D. \& Young, C. C. (2007). Lysobacter defluvii sp. nov., isolated from municipal solid waste. Int J Syst Evol Microbiol 57, 1131-1136. 